Review article

\title{
Resistance in Staphylococcus Aureus: The Never-Ending Story
}

\author{
Jovan Orlović$^{1}$, Biljana Miljković-Selimović ${ }^{2,3}$, Marina Dinić ${ }^{2,3}$, Ljiljana Ristić ${ }^{2}$ \\ ${ }^{1}$ University of Niš, Faculty of Medicine, PhD student, Niš, Serbia \\ 2University of Niš, Faculty of Medicine, Niš, Serbia \\ ${ }^{3}$ Public Health Institut, Niš, Serbia
}

\section{SUMMARY}

Combating Staphylococcus aureus (S. aureus) infections using antibacterial drugs is actually an ongoing effort to overcome resistance mechanism of this microorganism. In this paper, we discussed (1) the mechanisms of resistance to some of the most commonly used antimicrobial agents in the treatment of $S$. aureus: methicillin, vancomicyn and quinolones. In addition, (2) efflux pump mechanisms involved in maintaining homeostasis in the presence of compounds that inhibit S. aureus growth and reproduction, as well as mechanisms of resistance to a number of antibiotics, have been reviewed.

Key words: Staphylococcus aureus, resistance mechanisms, antimicrobials

Corresponding author:

Jovan Orlović

Email:jomj12@yahoo.com 


\section{INTRODUCTION}

It is considered that drug and multidrug resistance may raise the level of virulence factors in pathogenic bacteria. The mechanisms responsible for increased antimicrobial resistances in the Staphylococcus aureus ( $S$. aureus) include enzymatic inactivation of antibiotics, ( $\beta$ lactamases) decreased membrane permeability (methicillin resistance), alteration of binding sites (resistance to quinolones), presence of biofilms and active efflux of antimicrobials, which is included in resistance to many harmful substances including antibiotics (1).

In the early seventies of the last century, physicians were forced to abandon their belief that all bacterial infection can be cured by effective antimicrobial agents due to the fact that pathogens such as S. aureus, Streptococcus pneumoniae, Pseudomonas aeruginosa and Mycobacterium tuberculosis possess multiple antibiotic resistances. The development and increasing the number of bacterial strains resistant to antibiotics are based on a number of factors including the widespread and sometimes inappropriate use of antibiotics, extensive use of these agents as growth enhancers in animal feed and the increase in regional and international travel, which facilitated the transition of antibiotic-resistant bacteria across geographic barriers (2). An increasing number of multiresistant isolates of $S$. aureus can be seen worldwide among hospitalized patients in intensive care units and from hemocultures $(3,4)$. Therefore, nowadays we have fewer antibiotics for the treatment of life-threatening infections. Staphylococci are developing effective mechanisms of resistance at the same rate as the new drugs have been introduced in therapy.

New notifications of $S$. aureus isolates resistant to vancomycin opened a chemotherapeutic era with fear that effective antibiotics against this organism may no longer be available $(5,6)$. Considering that $S$. aureus can cause severe clinical manifestations, as well as infection in the hospital setting, the problem of its resistance is of great clinical significance. Namely, when penicillin was discovered, all tested strains of $S$. aureus were susceptible to penicillin. Today, virtually all strains of S. aureus express some of the mechanisms of resistance to this drug. Until now, several mecha-nisms by which $S$. aureus confers resistance to $\beta$-lactam antibiotics, quinolones and vancomycin have been discovered and clarified, which have the greatest significance for the treatment of infections caused by these strains. Furthermore, one of the major problems is the emer- gence of strains resistant to methicillin, the drug specially created for the treatment of $S$. aureus infection, in particular, methicillin-resistant $S$. aureus (MRSA). Staphylococci typically have one or more plasmids per cell that have different genes, mostly related to the mechanisms of resistance.

Generally, the genetic resistance can be determined at the level of chromosomes or plasmids. Staphylococci typically carry one or more plasmids, although it is mainly related to resistance mechanisms. They could be small ones that carry a single resistance determinant, slightly larger, which carry several resistance determinants and multiresistance plasmids (7).

\section{RESISTANCE TO B-LACTAM ANTIBIOTICS}

In $S$. aureus strains, resistance to $\beta$-lactams may be caused by enzymatic activity ( $\beta$-lactamase), changes in penicillin binding proteins (PBP), and efflux pumps.

Beta-lactamases can be divided according to the mode of action and chemical (molecular) structure. According to the mode of operation, that is, according to the specificity of the enzyme for a substrate, $\beta$ lactamases are divided into four groups (1 to 4) (8). Molecular classification of $\beta$-lactamases is based on the sequences of their nucleotide and amino acid. Until today, four classes are known (A to D or A, B, C, D) that are correlated with the functional classification. Class A, C and D have serine in the active site, while zinc is required for the operation of class $B(9)$.

\section{Activity of $\beta$-lactamases}

Most of the $\beta$-lactamases belong to the family of serine peptidase. These are enzymes produced by some bacteria and are responsible for resistance to $\beta$-lactam antibiotics, although they are relatively resistant to cephalosporins. Beta-lactamases breaks $\beta$-lactam ring through hydrolysis deactivating the molecule's antibacterial properties (10). The first identified type of $\beta$-lactamase was penicillin-specific penicillinase discovered before the practical application of penicillin (11).

The first group includes cephalosporinases, which belong to the molecular class $C$, and their performances are not inhibited by clavulanic acid. This group consists of Gram-negative bacteria's AMC enzymes $(12,13)$. The second group isdivided into several subgroups, while the group 3 are metalloenzymes of molecular class B, which also are not inhibited by clavulanic acid. 
The second group, divisible into several subgroups, are cephalosporinases and penicillinases, both inhibited by clavulanic acid, belonging to the molecular class A with exception of the subgroup $2 \mathrm{~d}$ that belongs to $A$ and D classes, reflecting the original TEM and SHV genes. Due to the increasing number of $\beta$ lactamases derived from TEM and SHV $\beta$-lactamases, they are divided into two subclasses, $2 a$ and $2 b(12,13)$. Subgroup $2 a$ contains only penicillinase. Subgroup $2 b$ contains a broad spectrum of $\beta$-lactamases that can inactivate penicillins and cephalosporins. This subgroup includes enzymes TEM-1, TEM-2, and SHV1. Additionally, some new sub-groups were derived from this subgroup $(12,13)$. Subgroup $2 b$ has an extended spectrum of action and the ability to inactivate third generation cephalosporins (ceftazidime, cefotaxime and cefpodoxime) and monobactams (aztreonam). This subgroup includes the enzymes TEM-3 to TEM-26 TEM, as well as SHV 2 to the SHV-6 $(12,13)$.

Subgroup $2 \mathrm{br}$ is resistant to inhibitors, since their activity is only reduced by the clavulanic acid. This subgroup includes enzymes TEM-30 and TEM-36 $(12,13)$. In the sub-group 2c fall carbenicillinase, PSE-1, PSE-3, and PSE-4 $(12,13)$. Subgroup $2 d$ contains oxacillinase. $2 \mathrm{~d}$ subgroup enzymes inactivate cloxacillin at higher rate than benzylpenicillin and certain rate of their activity was observed towards carbenicillin; clavulanic acid inhibits them poorly, and some of them belong to the ESBL. These enzymes can inactivate the oxazolylpenicillins such as oxacillin, cloxacillin, and dicloxacillin. Representatives of this group are OXA-1 to 11, the PSE-2 (OXA-2) (12,13). 2e subunit consists of cephalosporinases that can hydrolyze, and monobactams able to inhibit the clavulanic acid. These are inducible cephalosporinases produced by Proteus vulgaris $(12,13)$. Subgroup $2 \mathrm{f}$ is added because it includes carbapenemases originated from a serine, as opposed to those that have zinc and are included in group 3. In this group are NMC-A Enterobacter cloacae and SME-1 Serratia marcescens $(12,13)$.

In the group 3, there are metalloenzymes, molecular class $B$, not capable to inhibit the clavulanic acid. Group 3, metallo- $\beta$-lactamase, possess zinc and these are the only enzymes with metal ion (zinc) as part of active site. The metallo- $\beta$-lactamases are capable to hydrolysepenicillins, cephalosporins and carbapenems, while carbapenems can be inhibited by group $2 f$ (with serine in active site) and also by the members of group 3 (with zinc in active site).
Group 4 consists of penicillinases and still does not belong to any molecular class (not inhibited by clavulanic acid) $(12,13)$.

Some $\beta$-lactamases are called extendedspectrum beta-lactamases (ESBLs). ESBLs include: $\beta$ lactamases class A TEM SHV, CTX-M $\beta$-lactamases (class D), and OXA $\beta$-lactamases (PER, VEB, GES and IBC) (14). OXA $\beta$-lactamase inhibitors have long been known as being relatively rare, but localized in plasmids with the ability to hydrolyze oxacillin and similar anti-staphylococcal penicillin. They are responsible for the emergence of resistance to ampicillin and cephalothin, and they have a pronounced hydrolytic activity against oxacillin and cloxacillin. Clavulanic acid inhibits them poorly (15).

Although not belonging to ESBLs, inhibitorresistant $\beta$-lactamases are commonly referred as ESBLs, because they also arise from the classical TEM or SHVtypes of enzymes. There are at least 19 different TEM $\beta$ lactamases of that type. TEM variants resistant to the inhibitors are insensitive to clavulanic acid and sulbactam and show resistance to the combination of amoxicillin-clavulanic acid, ticarcillin-clavulanic acid, and ampicillin-sulbactam, though remain susceptible to the inhibition by tazobactam as well as to the combinations of the piperacillin/tazobactam. However, there are some of them resistant to these antibiotics. At present, these enzymes are mostly described in France and in several locations in Europe (16).

Gene blaZ is responsible for penicillin resistance of $S$. aureus. That gene carries the information for the synthesis of $\beta$-lactamase. This dominant extracellular enzyme, which is synthesized when exposed to staphylococcal $\beta$-lactam antibiotics, hydrolyzes the $\beta$ lactam ring, thereby inactivating it. Gen blaZ is controlled by two functionally opposed genes, blaR1 activator and bla1 repressor (17), responsible for the synthesis of regulatory proteins BlaR1 and BlaI. When exposed to $\beta$-lactam, BlaR1 works as a protease that degrades repressor BlaI, directly or indirectly, allowing blaZ gene to synthesize the enzyme (18).

\section{METHICILLIN RESISTANCE}

In all of methicillin-resistant $S$. aureus (MRSA) isolates, the gene responsible for methicillin resistance (mecA gene) is an integral part of mobile genetic elements found in all of MRSA isolates. Katayama et al. in 2000 showed that the mecA gene is a part of the sta- 
phylococcal cassette chromosome mec (SCCmec) (19). Thus far, description is given for the four different parts of the genomic SCCmec elements. They vary in size from 21 to 67 kilobases (kb) (20). For the synthesis of penicillin-binding protein 2a ( $\mathrm{PBP} 2 \mathrm{a}$, ) also named the PBP2, the gene of the size of $78-\mathrm{kDa}$ is responsible (21). Its activity depends on the serine protease activity from which it originated.

PBP is a membrane enzyme that catalyzes the transpeptidation necessary for the cross-linking of the peptidoglycan chain (22). In addition to innate resistance, gene mutations can lead to a reduction in the amount of PBP and decrease in the affinity of PBP to antibiotics. S. aureus has 'supernumerary' PBP (PBP2a or PBP2'), encoded by mecA gene located on transposon, which can be transmitted through transduction as well as conjugation. The regulation of this gene takes place at the level of transcription, therefore the detection of inducible, delayed inducible, and constitutive phenotype is possible (13).

Due to his low affinity to all antibiotics that posses $\beta$-lactam ring, PBP2a allows the survival of staphylococci exposed to high levels of these antibiotics. Accordingly, the resistance to methicillin indicates drug resistance to all $\beta$-lactam antibiotics. The soluble derivatives of PBP2a have crystal structure. Perhaps, that is why PBP2a differs from other PBPs in respect of its active site which not only blocks binding of all $\beta$-lactams, but allows the continuation of transpeptidation reaction (23).

Each MRSA strain is resistant to certain methicillin concentration, which is characteristic "fingerprinting" reflecting in an increase in the number of bacterial cells (24). Resistance expression in some MRSA strains is controlled by genes homologous to blaZ regulatory genes. Regulatory mecI and mecRI genes regulate the response of mecAtoa $\beta$-lactam antibiotics in a similar way that blaZ genes control the response to exposure to penicillin by the blaRI and blaI genes. The fact is that DNA sequence associated with repressor genes that achieve the inhibition of the gene is identical to the active ones (25). This similarity, between mecI-mecRI and blaRI-blaI regulatory genes that leads to the induction of expression of the mecA gene causes the possible emergence of an alternative way in the occurrence of resistance. The deletion or mutation in the mecI gene, or in the mecA promoter region, often leads to constitutive expression of mec (26). It has been found that mecI or blaI must be functional in all MRSA (27): that is why authors assumed its protective role in hyperproduction of toxic proteins. In contribution to the heterogeneous methicillin resistance, key role is played by an additional series of genes, fem genes (factor essential for methicillin resistance); their primary function is in the crosslinking of peptidoglycan (28).

In mecA gene sequence, more genes responsible for antimicrobial resistance can be found, insertion sequences, and genes with an unknown function. As a part of four SCCmec sequences two recombinases, ccrA and $\mathrm{ccrB}$ are recognized. Interestingly, they belong to invertase/resolvase family. For that reason they are responsible for site-specific integration and excision from the chromosome. That sequence of chromosome is a part of an open reading frame. The function of that sequence is not known and it is placed in the vicinity of the origin of replication at attBscc place $(29,30)$.

\section{RESISTANCE TO QUINOLONES}

The origin of resistance to quinolones is in chromosomal mutations. High concentration of bacteria in one place, probably as a presence of resistant strains of the subpopulation, and sometimes, limited concentration of quinolones, stimulate the emergence of resistant mutants (31). Quinolones affects the activity of DNA gyrase, weakening the bonds of DNA chain, whereas topoisomerase IV separates DNA chains. The change in amino acid sequences, in the corresponding region of the DNA enzyme complex (quinolone resistance determining region, $\mathrm{QRDR}$ ), reduces the affinity of the quinolones to the target sites. GrlA subunit (ParC) of topoisomerase IV and GyrA subunit of DNA gyrase are considered as the most common sites of the mutations that lead to the emergence of resistance to these drugs $(31,32)$. Sometimes, a single amino acid mutation is sufficient to get a clinical manifestation of the resistance, but for fluoroquinolones the occurrence of additional mutations is necessary. The mutations accumulate in QRDR region, increasing the degree of resistance. An additional mechanism of resistance in S. aureus is the induction of NorA efflux pump to discharge more drugs. The increasing in the expression of these pumps in $S$. aureus leads to the higher rates of resistance to quinolones (33). The bond between virulence and antimicrobial resistance is very interesting: it has been found that exposure of the strains already resistant to quinolones increases the expression of fibronectin-binding protein, the surface protein that allows the attachment of bacteria to the surface of a tissue, that is, the colonization (34). 


\section{RESISTANCE TO VANCOMYCIN}

Up till now, two mechanisms of $S$. aureus resistance to vancomycin were discovered. One of the mechanisms has been identified in vancomycin intermediate $S$. aureus (VISA) strains, wherein the MIC of vancomycin varies from $8-16 \mu \mathrm{g} / \mathrm{ml}$ (35). The decrease of susceptibility to vancomycin appears as a result of changes in the biosynthesis of peptidoglycan. VISA strains are characterized by the appearance of irregular shapes and thickening of the cell wall, because of the additional amount of synthesized peptidoglycan. Additionally, the reduction of crosslinks of peptidoglycan fibers leads to the greater exposure of D-Ala-D-Ala residues $(36,35)$. Modification of the cross-linking agent leads to a reduction of available amount of L-glutamine required for the amidation of D-glutamate in the peptidoglycan of the bridge (6). As a consequence, vancomycin binds to the greater number of D-Ala-D-Ala residues. The vancomycin then acts as a barrier, preventing further binding of drug molecules to the target in the cytoplasmic membrane (37). Conjugal transfer of the vanA operon of the vancomycin-resistant Enterococcus faecalis (E. faecalis) can lead to the resistance to vancomycin. A result of this process is probably the appearance of the VRSA strains which are completely resistant to vancomycin with $\mathrm{MIC}=128 \mathrm{mg} / \mathrm{ml}$. Changes in the terminal of the peptide chain caused the resistance of these strains, so that, instead of D-Ala-DAla, there is D-Ala-D-Lac. Synthesis of D-Ala-D-Lac only occurs where exposed to low concentrations of vancomycin (38).

There are several phenotypes of vancomycin resistance: VanA, VanB or VanC. VanA phenotype leads to the synthesis of the depsipeptide and its incorporation in the cell wall instead of in D-alanyl-Dalanine. In the case of VanB phenotype, the synthesis of ligase with the new specificity occurs, hence the termini of the peptidoglycan precursor have a D-lactate. Unlike the two previous phenotypes, in VanC resistance phenotype, there is D-Ser at the end of peptidoglycan precursors $(13,39)$.

\section{RESISTANCE DUE TO REDUCED PERMEABILITY OF THE OUTER MEMBRANE}

Mutations that lead to reduced manifestation of, or damage porins, are responsible for reducing the susceptibility to many antibiotics (1).

\section{RESISTANCE DUE TO ACTIVE PUMPING (ACTIVE EFFLUX) DRUG}

The introduction and widespread use of antibiotics has created selective pressure for the emergence of bacterial strains that would persist despite antibiotic toxicity. Not only the accumulation of resistance genes through the process of conjugal transfer but also the participation of the class of genes that encode membrane proteins can cause the appearance of multidrug resistant strains. Products of these later genes are named multidrug transporters. Whatever transporters are into question, each expels abroad spectrum of harmful substances for the cell as well as chemically unrelated drugs. These transporters may be classified in the group of defense mechanisms. These mechanisms are not rear and they are expressed in many species (40).

Efflux transporters allow the bacteria to create an important mechanism of resistance to antibiotics, by throwing out of the cell a large number of unwanted and harmful substances (41). Based on the source of energy used, they can be divided into two basic groups. The first group includes cassettes that bind adenosine triphosphate (ATP), that is, $\mathrm{ABC}$ transporters that use ATP as a source of energy, while another group, secondary transporters use electronic transmembrane proton or sodium ion gradients of. Competition may be an integral feature of secondary multidrug transport (42). The secondary transporters for a larger number of drugs are divided into four superfamilies according to the structure: 'major facilitator superfamily' (MFS); 'resistance-nodulationdivision' (RND), the family that owns three proteins; family transporter responsible for the discharge of a number of drugs and toxic compounds (the multidrug and toxic compound extrusion, MATE); family of small multidrug resistance transporter (small multidrug resistance, SMR) (43). 


\section{Efflux pumps in S. aureus}

There are several multidrug and drug-specific efflux pumps well described in S. aureus: Qac (A, B, G, H, J), LmrS, MdeA, Nor (A, B, C, D), SdrM Multidrug Efflux Pump; TetA(K), and Tet38 (Tetracycline Efflux Pumps).

\section{QacA and QacB multidrug efflux pumps}

The best descriptions of the efflux pumps in $S$. aureus are related to QacA and QacB transporters. Members of MFS family, QacA and QacB rely on the proton motive force and expression of their genes request the presence of regulator protein QacR, which is substrate- responsive. QacA protein is plasmidencoded, while the qacB determinant is only particularly plasmid-encoded (1). In S. aureus clinical isolates, the presence of the qacA and qacB is recorded in both MRSA (8\%) and MSSA (3.3\%) (44). pumps

QacG, QacH, and QacJ multidrug efflux

QacG, QacH, and QacJ, as multidrug efflux proteins in S. aureus, encoded by plasmids, with similar primary amino acid sequences, belong to the SMR family (1).

\section{NorA, NorB, NorC, and NorD multidrug efflux pump}

Most of these efflux pumps are regulated by chromosomally encoded genes, and confer the resistance to a wide variety of drugs.

NorA is also thoroughly investigated multidrug efflux pump of $S$. aureus. It can expel a wide spectrum of antimicrobial agents, among others fluoroquinolones. However, there are numerous inhibitors which inhibit the drug efflux system like reserpine, chalcone, capsaicin, and other efflux pump inhibitors:" thiopyranopyridine moiety, omeprazole derivatives, flavones, isoflavones, neohesperidosides, pentaester, spinosan A, pterocarpan, orizabin XIX, orizabin IX, epigallocatechingallate, epicatechingallate, coumarin epoxide, bergamottin epoxide, and piperidine alkaloids" (1).

NorB shares 30\% and 39\% aminoacid sequence similarity with efflux mechanisms of $S$. aureus NorA and QacA, respectively. NorB confers resistance not only to NorA substrates but also to some fluoro- quinolones and to tetracycline (1). NorC can be negatively regulated and possess $61 \%$ amino acid seqence similarity with NorB. This pump also confers resistance to fluoroquinolones (1). NorD consists of 12 domains and there is evidence that its expression is upregulated in subcutaneous abscess. It seems that substrates of NorD are not known. Although fur is a negative regulator of norD, the restriction of free iron upregulates norD expression (1).

\section{LmrS multidrug efflux pump}

LmrS is a proton-coupled multidrug antiporter (exchanger or counter-transporter) which belongs to MFS coded by chromosomal gene of the $S$. aureus. It very efficiently extrudes drugs such as lincomycin, kanamycin, linezolid, and fusidic acid often used in $S$. aureus infection therapy (1).

\section{MdeA multidrug efflux pump}

The mdeA gene is located on chromosome and encodes a multidrug efflux pump, MdeA, and conferring resistance to some fluoroquinolones such as norfloxacin. MdeA has a $23 \%$ identity of S. aureus QacA. Approximately $49 \%$ of the studied S. aureus strains isolated from blood, which means that they are invasive strains, possess overexpressed efflux pumps. MdeA overexpressing strains are also recorded as invasive strains (1).

\section{SdrM multidrug efflux pump}

SdrM is a multidrug efflux pump which belongs to MFS. It is probably energy-dependent and regulated by MgrA (1). It shows similarity to other transporters such as NorB and QacA. Mutation in mgrA gene may lead to the greater extent of expression from sdrM (Staphylococcus drug resistance) leading to the appearance of multidrug resistant strains (1).

\section{TetA(K) and Tet38 tetracycline efflux pump}

Tet $\mathrm{A}(\mathrm{K})$ is one of the plasmid-encoded MFS transporters and acts as an $\mathrm{Na}+(\mathrm{K}+) / \mathrm{H}+$ antiporter, showing a high level of resistance to tetracycline and some of its derivates (1). On the contrary, Tet38 determinant is encoded by chromosomal genes, and also belongs to MFS, conferring resistance to tetracycline. It is negatively regulated by MgrA, acting as SdrM efflux pump (1). 


\section{FUTURE PROSPECTS}

Considering resistance, an increase in resistance rates can be expected, especially in clinical isolates, against known efficient antimicrobials, and spreading of known resistance mechanisms to susceptible strains. The appearance of new resistance mechanisms in isolates previously sensitive to antibiotics used in the treatment of invasive $S$. aureus infections represent a specific problem requesting permanent monitoring and gaining available information on the resistant strains. Perhaps accumulation of knowledge about resistance genes and efflux mechanisms are the key factors for understanding the increasing resistance in invasive $S$. aureus strains.

\section{References}

1. Andersen JL, He GX, Kakarla P et al. Multidrug Efflux Pumps from Enterobacteriaceae, Vibrio cholerae and Staphylococcus aureus Bacterial Food Pathogens. Int J Environ Res Public Health 2015; 12:1487-547. http://dx.doi.org/10.3390/ijerph120201487

2. Cohen ML. Epidemiology of drug resistance: implications for a post-antimicrobial era. Science 1992; 257:1050-5. http://dx.doi.org/10.1126/science.257.5073.1050

3. Lowy FD. Staphylococcus aureus infections. N Engl J Med 1998; 339:520-32. http://dx.doi.org/10.1056/NEJM199808203390806

4. Diekema DJ, Pfaller MA, Schmitz FJ et al; SENTRY Partcipants Group. Survey of infections due to Staphylococcus species: frequency of occurrence and antimicrobial susceptibility of isolates collected in the United States, Canada, Latin America, Europe, and the Western Pacific region for the SENTRY Antimicrobial Surveillance Program, 19971999. Clin Infect Dis 2001; 32(Suppl. 2):S114S132.

http://dx.doi.org/10.1086/320184

5. Hiramatsu $\mathrm{K}$, Hanaki $\mathrm{H}$, Ino $\mathrm{T}$ et al. Methicillin-resistant Staphylococcus aureus clinical strain with reduced vancomycin susceptibility. J Antimicrob Chemother 1997; 40:135-6.

http://dx.doi.org/10.1093/jac/40.1.135

6. Centers for Disease Control and Prevention (CDC). Vancomycin-resistant Staphylococcus
aureus--Pennsylvania, 2002. MMWR Morb Mortal Wkly Rep 2002: 11;51:902.

7. Malachowa N, Frank R. Mobile genetic elements of Staphylococcus aureus. Cell Mol Life Sci 2010; 67: 3057-71. http://dx.doi.org/10.1007/s00018-010-0389-4

8. Bush LM, Calmon J, Johnson CC. Newer penicillins and beta-lactamase inhibitors. Infect Dis Clin North Am 1995; 9:653-86.

9. Ambler RP. The structure of betalactamases.Philos Trans R SocLond B BiolSci 1980; 289:321-31.

http://dx.doi.org/10.1098/rstb.1980.0049

10. Drawz SM, Bonomo RA. Three Decades of $\beta$ Lactamase Inhibitors. Clin Microbiol Rev 2010; 23: 160-201. http://dx.doi.org/10.1128/CMR.00037-09

11. Abraham EP, Chain E. An enzyme from bacteria able to destroy penicillin. 1940. Rev Infect Dis. 1988; 10(4):677-8.

12. Murray PR, editor. Manual of clinical microbiology, 7th edition. Washington, ASM Press, 1999.

13. Mirović V. Antibiotici i osnovni principi njihove kliničke primene. Čigoja štampa, Beograd, Beograd 2003.

14. Weldhagen GF, Poirel L, Nordmann P. Ambler class A extended-spectrum beta-lactamases in Pseudomonas aeruginosa: novel developments 
and clinical impact. Antimicrob Agents Chemother 2003; 47:2385-92.

http://dx.doi.org/10.1128/AAC.47.8.2385-2392.2003

15. Rubtsova MY, Ulyashova MM, Edelstein MV, Egorov AM. Oligonucleotide microarrays with horseradish peroxidase-based detection for the identification of extended-spectrum $\beta$ lactamases.BiosensBioelectron 2010; 26:1252-60. http://dx.doi.org/10.1016/j.bios.2010.06.053

16. Bradford PA. Extended-spectrum betalactamases in the 21st century: characterization, epidemiology, and detection of this important resistance threat. ClinMicrobiol Rev 2001; 14:933-51.

http://dx.doi.org/10.1128/CMR.14.4.933-951.2001

17. Gregory PD, Lewis RA, Curnock S, Dyke KG. Studies of the repressor (BlaI) of beta-lactamase synthesis in Staphylococcus aureus.MolMicrobiol 1997; 24:1025-37. http://dx.doi.org/10.1046/j.1365-2958.1997.4051770.x

18. Zhang HZ, Hackbarth CJ, Chansky KM, Chambers HF. A proteolytictransmembrane signaling pathway and resistance to betalactams in staphylococci. Science 2001; 291:1962-65.

http://dx.doi.org/10.1126/science.1055144

19. Katayama Y, Ito T, Hiramatsu K. A new class of genetic element, staphylococcus cassette chromosome mec, encodes methicillin resistance in Staphylococcus aureus. Antimicrob Agents Chemother 2000; 44:154955.

http://dx.doi.org/10.1128/AAC.44.6.1549-1555.2000

20. Kreiswirth B, Kornblum J, Arbeit RD et al. Evidence for a clonal origin of methicillin resistance in Staphylococcus aureus. Science 1993; 259:227-30.

http://dx.doi.org/10.1126/science.8093647

21. Ghuysen J.M. Molecular structures of penicillin-binding proteins and betalactamases. Trends Microbiol 1994; 2:372-80. http://dx.doi.org/10.1016/0966-842X(94)90614-9

22. Lim D, Strynadka NC. Structural basis for the beta lactam resistance of PBP2a from methicillin-resistant Staphylococcus aureus. Nat StructBiol 2002; 9:870-6.

23. Tomasz A, Nachman S, Leaf H. Stable classes of phenotypic expression in methicillinresistant clinical isolates of staphylococci. Antimicrob Agents Chemother 1991; 35:124-9. http://dx.doi.org/10.1128/AAC.35.1.124

24. Archer GL Bosilevac JM. Signaling antibiotic resistance in staphylococci. Science 2001; 291:1915-6. http://dx.doi.org/10.1126/science.1059671

25. Niemeyer DM, Pucci MJ, Thanassi JA et al. Role of mecA transcriptional regulation in the phenotypic expression of methicillin resistance in Staphylococcus aureus. J Bacteriol 1996; 178:5464-71.

26. Rosato AE, Kreiswirth BN, Craig WA et al. MecA-blaZcorepressors in clinical Staphylococcus aureus isolates. Antimicrob Agents Chemother 2003; 47:1460-3. http://dx.doi.org/10.1128/AAC.47.4.1460-1463.2003

27. Berger-Bachi B. Expression of resistance to methicillin. Trends Microbiol 1994; 2:389-93. http://dx.doi.org/10.1016/0966-842X(94)90617-3

28. Ito T, Katayama $\mathrm{Y}$, Hiramatsu K. Cloning and nucleotide sequence determination of the entire mec DNA of pre-methicillin-resistant Staphylococcus aureus N315. Antimicrob Agents Chemother 1999; 43:1449-58.

29. Hiramatsu K, Cui L, Kuroda M, Ito T. The emergence and evolution of methicillinresistant Staphylococcus aureus. Trends Microbiol 2001; 9:486-93.

http://dx.doi.org/10.1016/S0966-842X(01)02175-8

30. Archer GL, Niemeyer DM. Origin and evolution of DNA associated with resistance to methicillin in staphylococci. Trends Microbiol 1994; 2:343-47.

http://dx.doi.org/10.1016/0966-842X(94)90608-4

31. Høiby N, Jarløv JO, Kemp M et al. Excretion of ciprofloxacin in sweat and multiresistant Staphylococcus epidermidis. Lancet 1997; 349:167-9. 
http://dx.doi.org/10.1016/S0140-6736(96)09229-X

32. Ng EY, Trucksis M, Hooper DC. Quinolone resistance mediated by norA: physiologic characterization and relationship to flqB, a quinolone resistance locus on the Staphylococcus aureus chromosome. Antimicrob Agents Chemother 1994; 38:1345-55. http://dx.doi.org/10.1128/AAC.38.6.1345

33. Bisognano $\mathrm{C}$, Vaudaux $\mathrm{P}$, Rohner $\mathrm{P}$ et al. Induction of fibronectin-binding proteins and increased adhesion of quinolone-resistant Staphylococcus aureus by subinhibitory levels of ciprofloxacin. Antimicrob Agents Chemother 2000; 44:1428-37. http://dx.doi.org/10.1128/AAC.44.6.1428-1437.2000

34. Ince D, Zhang X, Hooper DC. Activity of and resistance to moxifloxacin in Staphylococcus aureus.Antimicrob Agents Chemother 2003; 47:1410-5.

http://dx.doi.org/10.1128/AAC.47.4.1410-1415.2003

35. Hiramatsu K, Aritaka N, Hanaki $\mathrm{H}$ et al. Dissemination in Japanese hospitals of strains of Staphylococcus aureus heterogeneously resistant to vancomycin. Lancet 1997; 350:16703.

http://dx.doi.org/10.1016/S0140-6736(97)07324-8

36. Walsh TR, Howe RA. The prevalence and mechanisms of vancomycin resistance in Staphylococcus aureus.Annu Rev Microbiol 2002; 56:657-75.

http://dx.doi.org/10.1146/annurev.micro.56.012302.160806

37. Hanaki $\mathrm{H}$, Labischinski $\mathrm{H}$, Inaba $\mathrm{Y}$ et al. Increase in glutamine-non-amidated muropeptides in the peptidoglycan of vancomycin-resistant Staphylococcus aureus strain Mu50. J Antimicrob Chemother1998; 42:315-20.

http://dx.doi.org/10.1093/jac/42.3.315
38. Sieradzki K, Roberts RB, Haber SW, Tomasz A. The development of vancomycin resistance in a patient with methicillin- resistant Staphylococcus aureus infection. N Engl J Med 1999; 340:517-23.

http://dx.doi.org/10.1056/NEJM199902183400704

39. Park IS, Lin $\mathrm{CH}$, Walsh CT. Bacterial resistance to vancomycin: Overproduction, purification, and characterization of VanC2 from Enterococcus casseliflavus as a D-Ala-D-Ser ligase. ProcNatlAcadSci USA 1997; 94:10040-4. http://dx.doi.org/10.1073/pnas.94.19.10040

40. Fluman N, Ryan CM, Whitelegge JP, Bibi E. Dissection of Mechanistic Principles of a Secondary Multidrug Efflux Protein. Molecular Cell 2012; 47: 777-87. http://dx.doi.org/10.1016/j.molcel.2012.06.018

41. Poole K. Efflux-mediated antimicrobial resistance. J AntimicrobChemother 2005; 56:2051.

http://dx.doi.org/10.1093/jac/dki171

42. Putman $\mathrm{M}$, van Veen HW, Konings WN. Molecular Properties of Bacterial Multidrug Transporters.MicrobiolMolBiol Rev 2000; 64: 672-93.

http://dx.doi.org/10.1128/MMBR.64.4.672-693.2000

43. Poole K. Outer membranes and efflux: the path to multidrug resistance in Gram-negative bacteria. Curr Pharm Biotechnol 2002;3:77-98. http://dx.doi.org/10.2174/1389201023378454

44. Ho CM, Li CY; Ho MW et al. High rate of qacA- and qacB-positive methicillin-resistant Staphylococcus aureus isolates from chlorhexidine-impregnated catheter-related bloodstream infections. Antimicrob Agents Chemother 2012; 56: 5693- 97. http://dx.doi.org/10.1128/AAC.00761-12 


\title{
Rezistencija Staphylococcus aureusa: priča koja se ne završava
}

\author{
Jovan Orlović1, Biljana Miljković-Selimovićc,3, Marina Dinić2,3, Ljiljana Ristićc \\ ${ }^{1} U$ iniverzitet u Nišu, Medicinski fakultet, student doktorskih studija, Niš, Srbija \\ ${ }^{2}$ Univerzitet u Nišu, Medicinski fakultet, Niš, Srbija \\ ${ }^{3}$ Institut za javno zdravlje, Niš, Srbija
}

\section{SAŽETAK}

Borba protiv infekcije bakterijom Staphylococcus aureus (S. aureus) upotrebom antibakterijskih lekova predstavlja neprestani napor da se prevaziđu mahanizmi rezistencije kojima ovaj mikroorganizam raspolaže. U ovom radu će biti razmatrani (1) mehanizmi rezistencije prema nekim od najčešće korišćenih antibiotika u terapiji $S$. aureus: meticilinu, vankomicinu i kvinolonima; (2) mehanizmi poput efluksne pumpe, koje učestvuju u održavanju homeostaze u prisustvu jedinjenja koja nepovoljno utiču na njegov rast i razmnožavanje, kao i mehanizmima rezistencije naveći broj antibiotika.

Ključne reči: Staphylococcus aureus, mehanizmi rezistencije, antibiotici 